\title{
(A)religijność po czesku - ateizm, analfabetyzm religijny czy coś więcej?
}

Streszczenie: Artykuł podejmuje próbę weryfikacji tezy: Współczesne społeczeństwo czeskie nie jest ateistyczne, nie jest też modelowym przykładem gwałtownej sekularyzacji. Przemiany zachodzące w społeczeństwie czeskim mają postać wielokierunkowych przemian religijności (transformacji), choć z silnymi tendencjami sekularyzacyjnymi. Świadczą o miękkiej, ale długotrwałej sekularyzacji, wyrażającej się w pluralizacji form religijnych, która utworzyła specyficzną i złożoną postawę współczesnego społeczeństwa czeskiego wobec religii.

Słowa kluczowe: współczesna religia, postsekularyzm, Republika Czeska, analfabetyzm religijny, pluralizm religijny

Kiedy mówimy o czeskim ateizmie, proponuję raczej pojęcie „cosizm”. To jest najbardziej rozpowszechniona wiara Czechów „W Boga wprawdzie nie wierze, ale coś nad nami musi być". "Cosizm” ma wiele postaci.

Tomáš Halík (2005) ${ }^{1}$

\section{Wprowadzenie}

W naukowej dyskusji prowadzonej w drugiej połowie XX wieku nad współczesną religijnością i jej trendami rozwojowymi w nowoczesnych społeczeństwach dominującą narracją była teza sekularyzacyjna zakładająca upadek religijności, zwłaszcza jej publicznych przejawów i przestrzeni wpływów w społeczeństwach, będący skutkiem modernizacji. Zakładano, że nieuchronną konsekwencją modernizacyjnych zmian społecznych - wzrostu dobrobytu, industrializacji, urbanizacji, technicyzacji, mobilności społecznej, wzrostu wykształcenia etc. - jest sekularyzacja, zmiana religijna przejawiająca się w obniżaniu się pozycji religii w społeczeństwie, coraz mniejszej jej obecności

1 Wszystkie przytoczone cytaty z publikacji w języku czeskim są tłumaczeniami autorki tekstu. 
w sferze publicznej, uniezależnianiu się pewnych dziedzin życia społecznego od wpływu instytucji religijnych, co w konsekwencji prowadzić miało w przyszłości do całkowitego zaniku religii (Wallace, 1966). Peter L. Berger przez proces sekularyzacji rozumiał „proces, dzięki któremu sektory społeczeństwa i kultury wyzwalają się spod dominacji instytucji i symboli religijnych" (2005, s. 150). Tezę tę zdawały się potwierdzać dane empiryczne, a nawet potoczna obserwacja przemian społecznych w większości krajów powojennej Europy: wzrastała liczba niewierzących lub obojętnych wobec religii, coraz mniej osób uczestniczyło w nabożeństwach niedzielnych, kościoły pustoszały, podobnie religijność skupiała się na starszej, wiejskiej i mniej wykształconej części populacji z dominacją kobiet. Tej charakterystyce nie odpowiadała sytuacja w Stanach Zjednoczonych, gdzie żadna masowa sekularyzacja rozumiana jak wyżej nie miała miejsce. Niemniej specyfika społeczeństwa amerykańskiego nie przeszkodziła uważać kraje europejskie za wzorzec, który naśladować będą inne społeczeństwa, również amerykańskie.

Globalna teoria sekularyzacji nie wytrzymała jednak próby czasu. W latach 70.-80. XX wieku została obalona. Jeden z autorów teorii, Peter L. Berger, wycofał się z tej opcji, pisząc w późniejszych pracach (1999, s. 2), że „współczesny świat wcale nie jest mniej religijny niż kiedykolwiek wcześniej, a w niektórych obszarach nawet bardziej" (dosłownie: furiously religious), co oznacza, że modernizacji społeczeństwa nie zawsze towarzyszy sekularyzacja, ale coraz większe zróżnicowanie religijne - pluralizm. Nowoczesność, zdaniem Bergera, jest nie tylko dość zróżnicowana, lecz - „w większości miejsc - także łatwa do pogodzenia z taką lub inną religią" (2007, s. 6). Dziś wiemy, że w społeczeństwach zachodnich coraz wyraźniej zachodzą zmiany społeczno-religijne, których nie można zrozumieć w obrębie teorii sekularyzacji, stała się ona nieadekwatna wobec współczesnej rzeczywistości. Jednym z pierwszych socjologów, który dostrzegł mankamenty teorii sekularyzacji i poddał ją krytyce, był Thomas Luckmann. W swojej koncepcji prywatyzacji i „niewidzialnej religii” (1967; 2006) zwrócił uwagę na głęboką metamorfozę religijności - wzrost indywidualnej duchowości kosztem (kościelnej) religijności, czyli zmiany plasujące się bardziej w świadomości jednostki niż w obszarach społecznych. W tym kontekście należy rozumieć przemiany religijności zachodzące w społeczeństwach europejskich, w których większość ludzi przestaje identyfikować się z tradycyjnymi Kościołami, co nie znaczy, że różne formy religijności nie odgrywają w ich życiu roli co więcej, wraz ze strachem przed „zderzeniem cywilizacji”, zwłaszcza zagrożeniem ze strony islamu, ich rola rośnie (Davie, 2000). 


\section{Postsekularyzm}

Badacze religii współczesną sytuację religii i świadomości religijnej Europy określają - za Jürgenem Habermasem - postsekularyzmem (Habermas, 2006). Koncepcja społeczeństwa postsekularnego Habermasa wskazuje na powrót religii do sfery publicznej, religii uczestniczącej w dyskursie publicznym, jednak pod warunkiem paralelnego występowania więcej rodzajów religijności, nie tylko tradycyjnych, reprezentowanych przez Kościoły (Habermas, 2009; Nešpor, 2018). Społeczeństwa demokracji liberalnej nie są zupełnie świeckie, lecz są postsekularnymi, czyli takimi, „gdzie w otoczeniu wciąż podlegającym sekularyzacji nadal istnieją wspólnoty religijne" (Habermas, 2002, s. 17), jednak życie bez wymiaru religijnego staje się powszechne, a wiara w Boga jest tylko jedną z opcji, bynajmniej nie najważniejszą (Taylor, 2007). Janusz Mariański przypomina, że rozpatrując zmiany religijności zachodzące w społeczeństwie postsekularnym, należy uwzględnić wiele uwarunkowań kontekstualnych o charakterze historycznym, w odwołaniu się do relacji Kościół - państwo, do tożsamości narodowych (2016, s. 11). Podkreśla też (2009), że niełatwa koegzystencja między religią a sekularyzmem jest możliwa wówczas, kiedy każda religia zaakceptuje pluralizm religijny, autorytet nauki i demokratyczny, konstytucyjny porządek państwa.

Przywołując znane zjawisko postsekularyzmu, obejmujące wiele procesów i symptomów wskazujących na powrót czynnika religijnego do życia społecznego, chcę zwrócić uwagę na przydatność postsekularyzmu w rozważaniach na temat współczesnej religijności społeczeństwa czeskiego, które należy prowadzić w szerszej niż sekularyzacyjnej perspektywie - w perspektywie postsekularyzmu europejskiego.

\section{Czesi - przykładem ateistycznego narodu?}

Jakkolwiek zjawisko sekularyzacji w Republice Czeskiej jest od kilku dekad najbardziej zauważalne spośród państw środkowoeuropejskich, a według najnowszych badań przeprowadzonych w ramach międzynarodowego projektu badawczego European Values Study w 2017 roku w europejskich krajach i regionach ${ }^{2}$ Czechy uzyskały najwyższy odsetek osób nieprzynależących do

2 Badania European Values Study [Europejskie Studia Wartości] to międzynarodowy projekt badań longitudalnych prowadzonych od 1981 roku w ponad 40 eu- 
żadnych organizacji religijnych (75\%), osób uważających siebie za niewierzących (50\%) bądź ateistów (14\%), (Rabušic i Chromková-Manea, 2018, s. 87), to w perspektywie postsekularnej Europy należy inaczej postrzegać (a)religijność społeczeństwa czeskiego. Zazwyczaj wnioskuje się o niej stereotypowo, głównie na podstawie instytucjonalnych aspektów sekularyzacji, takich jak wskaźnik przynależności do grupy wyznaniowej czy przejawy praktyk religijnych. Teza mówiąca o Czechach jako najbardziej zateizowanym narodzie jest daleko idącym uproszczeniem bazującym na stereotypowym postrzeganiu zjawiska religijności i braku znajomości specyfiki religijności współczesnych społeczeństw europejskich, zwłaszcza społeczeństwa czeskiego. Z uwagi na wysoki poziom prywatyzacji i indywidualizacji, jak też brak zaufania wobec tradycyjnych instytucji religijnych, religijność czeska jest fenomenem dużo bardziej skomplikowanym i niepodlegającym jednoznacznej kategoryzacji, co potwierdzają najnowsze badania świadomości religijnej i postaw społeczeństwa czeskiego wobec religii (por. Václavík i in., 2018; Nešpor, 2018).

W artykule próbuję zweryfikować i wykazać prawdziwość następującej tezy: Współczesne społeczeństwo czeskie nie jest modelowym przykładem gwałtownej sekularyzacji. Przemiany zachodzące w społeczeństwie czeskim mają raczej postać wielokierunkowych zmian religijności (transformacji), choć z silnymi tendencjami sekularyzacyjnymi. Swiadczą o miękkiej, ale długotrwałej sekularyzacji, wyrażającej się w pluralizacji form religijnych, która utworzyła specyficzną i złożoną postawę współczesnego społeczeństwa czeskiego wobec religii. Celem artykułu jest też próba znalezienia odpowiedzi na pytania: jakie są przyczyny zlaicyzowania i specyficznej religijności społeczeństwa czeskiego? na czym polega specyfika (a)religijności czeskiego społeczeństwa?

\section{Historyczne i społeczno-polityczne czynniki warunkujące przemiany religijności czeskiej}

Zasadnym jest spojrzeć na religijność społeczeństwa czeskiego przez pryzmat jej różnorakich uwarunkowań, co pozwoli nie tylko tę specyficzną religijność lepiej zrozumieć, ale również wyznaczyć związek pomiędzy nią i poziomem społecznej akceptacji religii. James Beckford uważa (2006), że społeczeństwa różnią się nie tylko poziomem zróżnicowania religijnego, lecz także pozio-

ropejskich krajach. Czeska Republika uczestniczyła w tych badaniach od roku 1990, następne fale badań miały miejsce w latach 1999, 2008, 2017. 
mem akceptacji różnych religii oraz religii jako takiej, co wynika z różnych uwarunkowań historycznych, społecznych, politycznych i ideologicznych. Założenia konstruktywistycznej koncepcji religii Jamesa Beckforda - wskazujące na konieczność poddania analizie złożonego kontekstu różnorakich uwarunkowań, wpływających na znaczenie religii i jej akceptację w konkretnej sytuacji społecznej - są szczególnie przydatne w przypadku religijności społeczeństwa czeskiego, zjawiska niełatwego do jednoznacznej oceny, bo uwikłanego w relacje Czesi - Kościół, zmieniające się pod wpływem historycznych, społecznych i politycznych uwarunkowań. Właściwe podejście do kwestii niezwykle skomplikowanej postawy współczesnego postsekularnego społeczeństwa czeskiego wobec religii wymaga analizy przemian religii i religijności w Czechach w kontekście historycznym, społeczno-politycznym i kulturowym (kształtowania tożsamości narodowej) oraz określenia czynników warunkujących te przemiany. Należy poszukać odpowiedzi na pytanie: jakie są i na czym polegają przyczyny zlaicyzowania i areligijności czeskiego społeczeństwa?

Niejednokrotnie jako główną przyczynę aktualnej sytuacji religijności i Kościołów w Czechach podaje się okres rządów komunistycznych i głębokich, traumatycznych ingerencji władzy totalitarnej w życie jednostek i społeczeństwa. Wprawdzie doświadczenia i przeżycia ludzi wyniesione z tego okresu niewątpliwie ukierunkowały (niekoniecznie negatywnie) rozwój religijności wielu osób, to jednak rozważanie jedynie tego czynnika jako głównej determinanty przemian religijności całego społeczeństwa czeskiego byłoby podejściem stereotypowym, schematycznym. Historycznych, społeczno-politycznych i kulturowych czynników, które kolejno powodowały zmiany religijności i postaw wobec Kościoła i doprowadziły do stanu dzisiejszego, było więcej i większość z nich miało miejsce przed okresem panowania rządów totalitarnych. Z drugiej strony należy przyznać rację założeniom, że skryty potencjał sekularyzacyjny, który formowany był i wyrastał z doświadczeń wcześniejszych generacji, w pełni ujawnił się w drugiej połowie XX wieku $\mathrm{w}$ atmosferze państwowego ateizmu i ułatwił reżimowi marginalizację religii w Czechach (Lužný i Navrátilová, 2001). Proces sekularyzacji jednak zaczął się dużo wcześniej niż w drugiej połowie XX wieku, jego przebieg należy prześledzić w kilku poprzednich stuleciach, zwłaszcza silnie zaznaczył się w wieku XIX - okresie kształtowania się czeskiej tożsamości narodowej.

Symboliczny początek czeskiej państwowości, jak też rozwoju czeskiej religijności ma miejsce na Morawach, kolebce czeskiego chrystianizmu. W latach 830-895 książęta wielkomorawscy kilkakrotnie przyjmowali chrzest 
- bądź to z rąk Niemców, w obrządku łacińskim, bądź od misjonarzy sołuńskich, Cyryla i Metodego, w obrządku słowiańskim. Takie rozchwianie i oscylacje pomiędzy różnymi opcjami religijnymi towarzyszyły rozwojowi religijności czeskiej od jej początków w czasach wielkomorawskich poprzez wieki aż do czasów współczesnych. Ten brak stabilności między innymi odróżnia religijność Czechów od religijności Polaków (por. Małysz, 2010).

Czynnikiem przywoływanym zwykle w pierwszej kolejności w związku z sekularyzacją narodu czeskiego jest husytyzm. Zapoczątkowany przez Jana Husa na praskim uniwersytecie konflikt między rodzimą myślą czeską a niemiecką myślą katolicką rozwinięty został w rewolucyjne działania ruchu husytów. Działania te przeciwstawiały się ideologicznym i politycznym wpływom Kościoła katolickiego, utożsamianego z panowaniem Niemców oraz ich kulturą i językiem. W ruch husycki i reformację szczególnie silnie zaangażowane były górne warstwy narodu. Wówczas na ziemiach czeskich doszło do podziału ludności pod względem religijnym, osłabienia środowiska katolickiego i stopniowej eliminacji katolicyzmu z życia publicznego, jako symbolu niemieckiej dominacji Habsburgów, na korzyść wyznań niekatolickich. Na początku XVII wieku czescy protestanci stanowili ponad 80\% społeczeństwa (Kadlec, 1991). Niemniej jednak nie można przypisywać czeskiemu narodowi charakteru „husyckiego” i w nim upatrywać głównej przyczyny wysokiej sekularyzacji czeskiego społeczeństwa. Husytyzm był ruchem religijnym, jednak z czasem zatracił swój religijny charakter i postrzegany był raczej jako ruch narodowy o silnym antyfeudalnym, antypapieskim i antyniemieckim rysie (Zenderowski, 2011). Religijne dziedzictwo "bożych bojowników” nie było tak żywotne, jak przypuszczano, zacierało się ono stopniowo w świadomości narodu czeskiego, który pod koniec XVII wieku w większości był z powrotem katolickim. Ówczesna Europa ciągle postrzegała Czechów jako naród husycki, zewnętrzni obserwatorzy nadal przypisywali Czechom husyckie usposobienie, choć oni sami je utracili. Obecnie wnikliwy ogląd problemu sprawił, że religioznawcy (por. Nešpor, 2010) za ważne źródło przemian sekularyzacyjnych i czeskiej niechęci do religii instytucjonalnej uważają nie sam husytyzm, lecz jego późniejszą, dziewiętnastowieczną recepcję i nacjonalistyczną reinterpretację podkreślającą w husytyzmie walkę społeczną i narodowościową, a jednocześnie ostro krytykującą Kościół rzymskokatolicki jako antyczeski i antynowoczesny. Niemniej konflikty i walki międzywyznaniowe mające miejsce tak w okresie ruchu husyckiego i reformacji, jak i podczas wojny trzydziestoletniej spowodowały zmiany w obszarze religii w Czechach - osłabienie pozycji Kościołów, co więcej, poprzez połączenie religii z poli- 
tyką i umocnienie politycznych funkcji religii, osłabienie jej podstawowych funkcji.

Kolejnym ważnym czynnikiem w zrozumieniu stosunku Czechów wobec religii, zwłaszcza wobec Kościoła katolickiego, był okres panowania Habsburgów i przymusowa, choć często powierzchowna, rekatolizacja narodu czeskiego. Habsburgowie byli katolikami i wykorzystywali religię do umacniania swego panowania. Dynastia ta w świadomości zbiorowej Czechów mocno kojarzyła się z katolicyzmem, stąd Kościół katolicki utożsamiany był z religią państwową zaborcy. Szczególnie dwa historyczne wydarzenia nie przyniosły Kościołowi katolickiemu chluby, a wręcz w świadomości Czechów zostały odebrane jako największe upokorzenia narodu czeskiego: ekskomunika i spalenie na stosie Jana Husa (1415) za to, że nawoływał hierarchię do powrotu do ewangelicznych źródeł wiary, oraz - po przegranej przez stany czeskie bitwie z wojskami habsburskimi pod Białą Górą (1620) - brutalna egzekucja „kwiatu narodu czeskiego” na Rynku Staromiejskim w Pradze, 27 wybitnych przywódców szlachty czeskiej, w większości protestantów. Wydarzenia te urosły do rangi symboli narodowych. Po Białej Górze Czechy utraciły niezależność i zostały wcielone do imperium habsburskiego. Rekatolizacja kraju prowadzona w ramach kontrreformacji szczególnie silnie dotknęła czeskie elity intelektualne środowisk niekatolickich, zwłaszcza duchownych i nauczycieli. Osoby, które odmówiły przejścia na katolicyzm, zmuszane były do emigracji (Kadlec, 1991). Taki los spotkał m.in. wybitnego myśliciela i pedagoga, prekursora nowoczesnej pedagogiki, Jana Amosa Komeńskiego. Trudne wydarzenia związane z przymusową rekatolizacją kraju spowodowały, że Kościół został przez Czechów zapamiętany i zaczął funkcjonować w zbiorowej świadomości jako narzędzie zniewolenia przez obcą władzę, okupującą kraj. Jakkolwiek w późniejszym okresie władza ta nie była już tak opresyjna, należy przyznać, że postępowanie Habsburgów przyniosło zarówno narodowi czeskiemu, jak i Kościołowi więcej szkody niż pożytku. Uważane jest za jedno z ważnych źródeł antyklerykalnych i antykatolickich postaw społeczeństwa czeskiego.

Przypuszczalnie kluczowym w zrozumieniu współczesnej czeskiej religijności był wiek XIX i mające wówczas miejsce czeskie odrodzenia narodowe (národní obrozenî). Okres ten stworzył podwaliny czeskiej nieufności wobec instytucjonalnych form religijności. Zasadnicze jego znaczenie dla kształtowania czeskiej mentalności religijnej polega na recepcji, a przede wszystkim na nacjonalistycznej reinterpretacji ruchu husyckiego. Przywódcy czeskiego odrodzenia narodowego, w większości wyznania ewangelickiego, m.in. „oj- 
ciec narodu" František Palacký, Pavel Josef Šafařík oraz poeta i ksiądz Jan Kollár, nadali mu antykatolicki charakter, co prowadziło do coraz mniejszego społecznego zaufania do Kościoła katolickiego, a w konsekwencji generalnie do wszystkich instytucji religijnych. Wobec antykatolickiego ruchu odrodzeniowego czeska świadomość oraz tożsamość narodowa od początku kształtowały się w opozycji do katolicyzmu, w wyniku czego udział treści religijnych (chrześcijańskich) w formowaniu tożsamości narodowej jest w Czechach jednym z najniższych w Europie (Vlachová-Řeháková, 2004).

Innym ważnym czynnikiem przemian religijności czeskiego społeczeństwa było, według Davida Václavíka (2010), przyjęcie na przełomie XIX i XX wieku narodowo-liberalnych idei formowania nowoczesnej czeskiej tożsamości narodowej. Poglądy narodowych liberałów były silnie antyklerykalne i antykatolickie. Propagowali antykatolicką interpretację historii czeskiej, podkreślając antyczeski charakter katolicyzmu i postrzegając działania Kościoła katolickiego jako negatywne dla narodu czeskiego. Prowadziło to do kształtowania negatywnych postaw społeczeństwa czeskiego wobec Kościoła katolickiego, a szerzej - wobec jakiejkolwiek instytucjonalnej formy religijności, którą Czesi odczuwali jako ograniczającą ich wolność. Dlatego w sytuacji odzyskania niepodległości, po rozpadzie monarchii austro-węgierskiej w roku 1918, ludzie manifestowali swoją wolność, odchodząc od Kościoła katolickiego. W 1920 roku tzw. ruch reformatorski założył własny narodowy Kościół o nazwie Czechosłowacki Kościół Husycki, do którego odeszło z Kościoła katolickiego około miliona wiernych. Władze polityczne nowej Republiki, na czele z pierwszym prezydentem Czechosłowacji Tomášem Garrigue Masarykiem, zaczęły budować państwowość opartą na demokratycznych ideałach i wartościach, w tym wartościach religijnych. Masaryk jednak powiązał czeską ideę narodową z tradycją husycką, gdyż uważał, że w husytyzmie i reformacji idea czeska stała się ideą uniwersalną, a religia zyskała bardziej autentyczny charakter. Odcięcie się od Kościoła katolickiego usankcjonowało antyklerykalizm, który stał się znaczącym elementem systemu politycznego państwa czechosłowackiego oraz podstawowym kluczem interpretacyjnym czeskiej tożsamości narodowej. Stąd wywodzą się źródła niemalże powszechnego antyklerykalizmu we współczesnym społeczeństwie czeskim. Wysoki stopień sekularyzacji Czechów ewidentnie połączony jest z brakiem zaufania wobec instytucji religijnych, zwłaszcza wobec Kościoła rzymskokatolickiego.

Refleksja poszukująca wyjaśnienia przemian religijności prowadzących do sekularyzacji czeskiego społeczeństwa byłaby niepełna, gdyby poza wyżej wymienionymi - jakkolwiek niezwykle istotnymi w świetle koncepcji społe- 
czeństwa postsekularnego - czynnikami warunkującymi przemiany religijności czeskiej nie uwzględniono procesu modernizacji i jego konsekwencji w obszarze religii. W Czechach proces modernizacji przebiegał w sposób niezwykle szybki i głęboki, co w połączeniu z religijną jednorodnością społeczeństwa wyznaczyło kierunek zmian zachodzących od drugiej połowy XIX wieku w tradycyjnym społeczeństwie czeskim, w tym negatywnych zmian w obszarze religijności, zwłaszcza instytucjonalnej (Václavík, 2010). Kiedy znaczenie i zaufanie do instytucji religijnych spadały, a wzrastał antyklerykalizm, społeczeństwo nie szukało alternatywnych rozwiązań w innych nurtach i grupach religijnych, lecz tradycyjną religijność i religijny obraz świata stopniowo zastąpiło religijnością formalną, prywatną, indyferentną, wreszcie powszechnym sceptycyzmem i obojętnością wobec religii. Jak podkreśla D. Václavík (2010), żadne inne społeczeństwo środkowoeuropejskie nie znalazło się w podobnej sytuacji, ponieważ albo było religijnie bardziej zróżnicowane (np. społeczeństwo niemieckie), albo proces modernizacji przebiegał dużo łagodniej (m.in. w Polsce).

Potwierdzeniem wcześniejszych, długofalowych tendencji sekularyzacyjnych i niebagatelnym, niejako „wieńczącym dzieło” czynnikiem warunkującym współczesną (a)religijność Czechów były działania podjęte wobec Kościołów i wspólnot religijnych w powojennej Czechosłowacji. Władze komunistyczne, wykorzystując panujący w społeczeństwie czeskim antyklerykalizm, zaczęły przekonywać ludzi, że antyklerykalizm jest postawą obywatelską i że należy odrzucić religię jako fałszywą ideologię, służącą legitymizacji ucisku klasowego. W stosunku do Kościoła i kleru podjęto szereg działań represyjnych - kontrole poczynań biskupów i księży, zastraszanie, szantażowanie, odbieranie nieposłusznym i zaangażowanym w pracę z młodzieżą duchownym zgody państwowej na wykonywanie posługi duszpasterskiej, usuwanie ich z parafii, w końcu skazywanie na więzienie. Wierzący publicznie przyznający się do wiary i niekryjący się z praktykowaniem byli szykanowani i zastraszani. Szczególnie dotyczyło to urzędników państwowych i nauczycieli. W wyniku takich prosekularyzacyjnych działań poziom religijności społeczeństwa zaczął spadać, a życie religijne zostało wyrugowane ze sfery publicznej do prywatnej (szerzej zob. Różańska, 2015). Represyjne działania władz komunistycznych, ograniczające wolność religijną znacznej części społeczności czeskiej, miały miejsce - $\mathrm{z}$ różną intensywnością - w całym okresie powojennym, w latach 1948-1989, za wyjątkiem krótkiego „okresu wolności” w latach 1967-1968. Niemniej pod koniec swego istnienia komunistyczny reżim doszedł do przekonania, że jego usiłowania mimo wszystko poniosły 
klęskę (Jandourek, 2010). Udało mu się zniszczyć organizacyjną strukturę Kościoła, ale nie zdołał go całkowicie zlikwidować. Nie zdołał zniszczyć małych wspólnot Kościoła podziemnego, które stały się nowym zaczynem odbudowy Kościoła po zmianach polityczno-ustrojowych i uzyskaniu wolności, w nowych, demokratycznych warunkach życia społecznego w latach 90. XX wieku.

Sedno sekularyzacji czy wręcz ateizacji czeskiego społeczeństwa nie tkwi jedynie w drugiej połowie XX wieku i represjach, których ono boleśnie doświadczyło ze strony władz komunistycznych ${ }^{3}$. Dla współczesnych czeskich postaw wobec religii decydujące znaczenie miało więcej czynników, jak wcześniej pokazano: dziewiętnastowieczne odrodzenie narodowe z reinterpretacją tradycji husyckiej; przywrócenie pamięci o działaniach kontrreformacyjnych oznaczających de facto zniszczenie narodu w XVII wieku'; poglądy intelektualistów, na czele z T. G. Masarykiem, tworzących na początku XX wieku podstawy niepodległej państwowości i czeskiej tożsamości narodowej opartej na idei husyckiej; odgórna ateizacja okresu komunistycznego, niezwykle skuteczna, trafiwszy na podatny grunt, dokonała dzieła.

\section{Religijność Czechów współcześnie - próba kategoryzacji}

Aktualna sytuacja religijności w Czechach, ze względu na specyficzne rysy, trudno poddaje się jednoznacznemu opisowi. Można nazwać ją „areligijnością", terminem, który do opisu religijności we wschodnich landach niemieckich przyjął niemiecki teolog Eberhard Tiefensee (za: Mariański, 2010), niemniej wydaje się równie dobrze pasować do społeczno-religijnej kondycji społeczeństwa czeskiego. Areligijność opisuje sytuację, w której temat religii i wiary właściwie dla społeczeństwa nie istnieje. Człowiek areligijny, jeżeli mimo woli zetknie się z problematyką religijną, z trudem ją zrozumie, ponieważ jest mu całkowicie obca. Co więcej, utrudniony, a wręcz niemożliwy jest

3 Należy podkreślić, że konsekwencje ingerencji władzy totalitarnej w religijne życie społeczeństwa nie były u wszystkich osób negatywne. W różny sposób warunkowały rozwój religijności: u jednych traumatyczne doświadczenia i lęk przed szykanami prowadziły do zobojętnienia religijnego, innym trudne przeżycia, a nawet prześladowania, ukierunkowały i pogłębiły religijność.

4 Zakres działań kontrreformacji w Czechach był tak wielki, że oznaczał zniszczenie narodu, totalne zwłaszcza w przypadku wyższych warstw społecznych, ale też w aspekcie ogólnej populacji kraju, która w XVII wieku spadła z 4 do 1,5 miliona mieszkańców. 
u niego sam odbiór i odczuwanie sacrum, gdyż pozbawiony jest wrażliwości na transcendencję, podobnie jak człowiek niemający słuchu muzycznego ma trudności z odbiorem utworu muzycznego. Tak kategoryczną tezę na temat stanu religijności społeczeństwa czeskiego można sformułować na przykład po pobieżnej analizie danych statystycznych ze spisów ludności i tworzonej na ich podstawie struktury wyznaniowej, w której faktycznie większość społeczeństwa nie przynależy do żadnej instytucji wyznaniowej. Taki obraz czeskiej religijności kreują również niektóre media - jak czeskie, dla których niereligijność narodu jest powodem do dumy, tak i zagraniczne. Jest to jednak zbyt ogólnikowa, powierzchowna i raczej stereotypowa ocena czeskiej religijności.

Czeski filozof Jan Patočka w znanym eseju Kim sq Czesi nazwał specyficzną religijność czeską „chrześcijaństwem laickim” (1997, s. 16). Kategoria ta znacznie lepiej niż areligijność przystaje do typu religijności, który reprezentują Czesi: odrzucając instytucjonalne, kościelne formy religii, zachowują zsekularyzowane wartości religijne, które nadal stanowią istotny element ich tożsamości narodowej (por. Zenderowski, 2011). W podobny sposób opisał czeską religijność Tomáš Halík, filozof, teolog i socjolog, nazywając ją „płochliwą, dyskretną pobożnością" („plachá zbožnost”) (Halík i Dostatni, 2011, ss. 52-55). Określił tak specyficzny sposób poszukiwań duchowych istniejący w kulturze czeskiej od czasów oświecenia. Religijność czeska nie manifestuje się poprzez wielkie słowa i gesty, ponieważ Czesi nie lubią patosu, kojarząc go z nieszczerością, hipokryzją i napuszaniem się. Nikt spośród wielkich osobistości czeskiej kultury XIX i XX wieku, przedstawicieli inteligencji, artystów, pisarzy, naukowców - można na przykład wymienić takie nazwiska, jak" František Palacký, Karel Havlíček Borovský, Tomáš G. Masaryk, Karel Čapek, Jan Patočka, Václav Havel - nie był typowym ateistą, a raczej wszystkich charakteryzował głęboki stosunek do „tego, co nas przerasta”, chociaż każdy utrzymywał dystans wobec tradycyjnej terminologii religijnej. Religijność Czecha, daleka od patetyczności, jest raczej dyskretna, „jak gdyby stale czuł on na sobie ironiczne spojrzenie niewierzącego" (Halík, Dostatni, 2011, s. 52). I ten typ religijności dyskretnej i kruchej, ale jednak religijności, a nie ateizmu, wydaje się najbardziej charakterystyczny dla współczesnego społeczeństwa czeskiego. Potrzebę rozróżnienia specyficznej czeskiej religijności od ateizmu podkreśla m.in. religioznawca D. Václavík, tłumacząc, że nie można postrzegać jako ateistów ludzi, którzy wprawdzie nie chcą być kojarzeni z żadną instytucją religijną lub nie przykładają do religii zbyt dużej wagi, równocześnie jednak identyfikują się z religijną interpretacją świata 
oraz biorą udział w określonych praktykach religijnych czy duchowych. Autor pisze: „Spotykamy się tutaj z istotnym problemem natury metodologicznej - dla adekwatnego zrozumienia religijności czeskiego społeczeństwa jest wprost kluczowym rozróżnienie ateizmu od »nieinstytucjonalnej religijności« i religijnego indyferentyzmu" (2010, s. 82).

Halík, polemizując ze stereotypowym postrzeganiem społeczeństwa czeskiego jako społeczeństwa ateistycznego, wskazuje na analfabetyzm religijny jako kategorię, której przywołanie jest niezbędne dla zrozumienia czeskiej religijności. Analfabetyzm religijny polega na braku podstawowej wiedzy religijnej (bądź posiadaniu jej w ograniczonym stopniu) i niezrozumieniu głównych prawd wiary. Może przejawiać się w mechanicznym i bezrefleksyjnym wykonywaniu praktyk religijnych, bez zgłębiania treści wiary, z czym spotykamy się w społeczeństwach tradycyjnie religijnych, m.in. w społeczeństwie polskim, sprzyja też bezrefleksyjnemu przyjmowaniu idei religijnych, również tych, które mają charakter integrystyczny, fundamentalistyczny czy wręcz ksenofobiczny" (Milerski, 2009, s. 6). Analfabetyzm religijny w społeczeństwie postsekularnym może implikować ignorancję religii nie poprzez jej świadome odrzucenie, lecz dlatego, że właściwie nigdy nie była przedmiotem zainteresowania. T. Halík wskazuje, że w czeskim zsekularyzowanym społeczeństwie tacy analfabeci religijni mylnie uważani są za ateistów. Ludzie mają negatywne opinie na temat religii, ale zazwyczaj nie wynikające z głębszego osobistego doświadczenia lub solidnej wiedzy. Religia ich nie interesuje, nic nie wiedzą na jej temat (2015, s. 22). I dodaje, że w tym przypadku wskazana byłaby swoista pedagogizacja osób odpowiedzialnych za kształtowanie opinii publicznej w edukacji i mediach. Swoista alfabetyzacja wiary staje się jednym z najważniejszych zadań, i to nie tylko z perspektywy typowo religijnej, lecz również w znaczeniu społecznym (por. Milerski, 2009).

Aktualny stan liczbowy wyznawców i członków wszystkich Kościołów oraz oficjalnych wspólnot wyznaniowych jest, w porównaniu z wcześniejszymi latami, dużo niższy. Czy wobec tego zmniejszył się poziom religijności społeczeństwa czeskiego, czy tylko doszło do zmiany formy religijności? Wyniki badań socjologów religii raczej potwierdzają tę drugą opcję, zmianę religijności. Oznacza to, że w społeczeństwie czeskim, podobnie jak w społeczeństwach innych krajów środkowoeuropejskich, coraz częściej spotkać można tzw. religijność „mieszaną”, powstającą poprzez hybrydyczne łączenie rodzimych (chrześcijańskich) i obcych idei religijnych (Rabušic i Chromková-Manea, 2018), ale też elementów astrologii, magii, religii neopogańskich czy nowych ruchów religijnych. W świetle wyników badań European Valu- 
es Study w roku 2017 26\% Czechów wierzyło w reinkarnację, podczas gdy w roku 2008 było to 16\%, a w 1991 roku 11\% (Rabušic, Chromková-Manea, 2018, s. 92). To przesunięcie religijności z obszarów religii tradycyjnej, zorganizowanej, instytucjonalnej w kierunku indywidualnych wierzeń potwierdza między innymi Dana Hamplová pisząc: „Czesi nie odrzucają nadprzyrodzoności jako całości, ale raczej tradycyjne zorganizowane systemy i religijność zorganizowaną, co prowadzi ich do wiary skierowanej na człowieka, polegającej na fatalizmie bądź okultyzmie" (2013, s. 15).

Ta prywatna religia jest często niespójna z oficjalnymi doktrynami Kościołów chrześcijańskich. Religioznawcy takie synkretyczne, rozmyte i subiektywne systemy przekonań religijnych charakterystyczne dla społeczeństwa czeskiego nazywają, parafrazując termin płynnej rzeczywistości Z. Baumana, „płynną wiarą" (Václavík, 2010, s. 159).

Jakie treści zawiera religijność Czechów, jeśli w większości odrzucają oni tradycyjny kanon wierzeń, doktryn i zasad religii chrześcijańskiej? Przywołajmy wyniki ogólnoczeskich badań przeprowadzonych w Instytucie Socjologicznym Czeskiej Akademii Nauk (Hamplová, 2008, s. 24): w osobowego Boga wierzy tylko 10\% badanych, w istnienie „określonej formy ducha lub siły życiowej” - 25\%, w „jakąś siłę wyższą" - 14\%. Niewielka grupa badanych (15\%) oświadczyła, że „nie istnieje żaden Bóg, ani duch, ani żadna siła wyższa" - tych można by określić jako ateistów, zaś pozostali to agnostycy - 22\% („nie wiem, ale chciałbym wiedzieć”) i obojętni - 11\% („nie wiem i nie interesuje mnie to). Podobne badania zostały przeprowadzone wśród młodzieży pogranicza polsko-czeskiego, na ich podstawie można wnioskować, że większość Czechów w „coś” wierzy: osobowego Boga, siłę wyższą, określoną formę ducha, dobro, przeznaczenie, siebie, świętość przyrody. Jedna z uczestniczek badań tak określiła swoją religijność: „nie chodzę do kościoła, nie wierzę w osobowego Boga, ale jestem religijna, bo odczuwam świętość obecną w przyrodzie" (Różańska, 2015, s. 317). Zdaniem Halíka dominującą religią Czechów nie jest katolicyzm, nie jest też ateizm, ale tzw. „cosizm”. Tak Halík nazwał wiarę ludzi w "coś, co istnieje nad nami”, mających poczucie istnienia „jakiejś siły wyższej” i/lub umiejscawiających przedmiot swej wiary w pozareligijnych obszarach (Halík i Dostatni, 2011, s. 45; Halík, 2004, s. 14). Nieraz podkreślał też, że jest to „najbardziej rozszerzona religia” w Czechach, przedstawiając w ten sposób sytuację religijności społeczeństwa czeskiego. Taki rodzaj religijności nazywany też jest - z uwagi na jej niedookreśloność i mozaikowatość co do wierzeń i zasad postępowania - „miękką duchowością" (Jandourek, 2010, s. 83). 
Reasumując, należy przyjąć, że konsekwencją przemian religijności społeczeństwa czeskiego jest nie tylko sekularyzacja w rozumieniu spadku znaczenia religii towarzyszącego procesowi modernizacji, ale wielka pluralizacja religii. Współczesne społeczeństwo czeskie nie jest ateistyczne (chociaż większość Czechów nie należy do żadnego Kościoła czy związku wyznaniowego), ale charakteryzuje się wielką pluralizacją form religijnych. Na to spektrum różnorodności czeskich postaw wobec religii z jednej strony składają się - tradycyjne, kościelne i wyznaniowe formy religijności (zróżnicowane też wewnątrz swojej instytucji), poprzez specyficzne formy nietradycyjnej religijności/duchowości (wspólnymi wyznacznikami tutaj są: brak przynależności do instytucji religijnej, brak poczucia ważności wspólnoty religijnej, poszukiwanie sensu życia poza obszarami wyznaczonymi przez tradycyjną religię, brak odniesienia do osobowego Boga, prywatyzacja religii, nieokreśloność przedmiotu wierzeń), a drugi koniec spektrum tworzą jednostki indyferentne, agnostycy i ateiści.

Na koniec przywołam zdanie Yuval Noah Harari, i nie chodzi o to, by je traktować jako smutną konstatację epilogową, lecz raczej jako przestrogę przed oceniającym porównywaniem i osądami wraz z przypisywaniem sobie wyższej oceny: „Każda religia, ideologia i każde wyznanie ma swoją mroczną stronę, więc bez względu na to, w co każdy z nas wierzy, powinien tę mroczną stronę uznać, unikać zaś naiwnych zapewnień w rodzaju: «nam się to nie może przydarzyć»" (2018, s. 276).

\section{Bibliografia}

Beckford, J. 2006. Teoria społeczna a religia. Kraków: Zakład Wydawniczy „NOMOS”.

Berger, P.L. 2005. Święty baldachim. Elementy socjologicznej teorii religii. Kraków: Zakład Wydawniczy „NOMOS”.

Berger, P.L. 2007. Między relatywizmem a fundamentalizmem. W drodze.9, Ss. 4-20.

Berger, P.L.,1999. The desecularization of the world. Resurgent religion and world politics. Washington: Grand Rapids.

Davie, G. 2000. Religion in modern Europe. A memory mutates. Oxford: Oxford University Press.

Foucault, M. 1993. Nadzorować i karać. Narodziny więzienia. Warszawa: Wydawnictwo Aletheia-Spacja. 
Habermas, J. 2002. Wierzyć i wiedzieć. Znak. 3, ss. 8-21.

Habermas, J. 2006. Religion in the public sphere. European Journal of Philosophy. 14 (1), pp. 1-25.

Habermas, J. 2009. Zwischen Naturalismus und Religion. Philosophische Aufsätze. Frankurt am Main: Suhrkamp Verlag.

Halík, T. 2004. Církev a „částečně identifikováni”. Universum. 9, ss. 14-15.

Halík, T. 2005. O ateizmu, pochybnostech a víre. - http://halik.cz/cs/tvorba/ clanky-eseje/nabozenstvi-spolecnost/clanek/45/ (20.11.2013).

Halík, T., Dostatni, T. 2011. Smírená různost (rozhovor). Praha: Portál.

Halík, T. 2015. Není ateista jako ateista. Lidové Noviny 14.11.2015, załącznik Orientace.

Hamplová, D. 2013. Náboženství v české společnosti na prahu 3. tisíciletí. Praha: Karolinum.

Hamplová, D., 2008. Religiozita dospělých v České republice na počátku 21. století. W: Lužný, D. i Nešpor, Z.R. red. Náboženství v menšině. Religiozita a spiritualita v současné české společnosti. Praha: Malvern, ss. 20-32. Harari, Y. N. 2018. 21 lekcji na XXI wiek. Kraków: Wydawnictwo Literackie. Jandourek, J. 2010. Vzestup a pád moderniho ateizmu. Praha: Grada Publishing, a.s.

Kadlec, J. 1991. Přehled českých církevních dějin. Praha: Zvon.

Luckmann, T. 1967. The invisible religion. The problem of religion in modern society. New York: Macmillan.

Luckmann, T. 2006. Niewidzialna religia. Kraków: Zakład Wydawniczy „NOMOS".

Lužný, D. i Navrátilová J., 2001. Náboženství a sekularizace v České republice. Sociální studia. T. 6, ss. 111-125.

Małysz, B. 2010. Porównanie Czechów i Polaków pod względem religijności. W: Szymeczek, J. red. Náboženská otázka ve výchově a vzdělávání v Československu (ČR a SR) v letech 1918-2008. Ostrava: Ostravská univerzita. Mariański, J. 2009. Sekularyzacja a nowe formy religijności. Roczniki Nauk Społecznych, t. 1 (37), ss. 33-68.

Mariański, J. 2010. Religia w społeczeństwie ponowoczesnym. Warszawa: Oficyna Naukowa.

Mariański, J, 2016. Religia i religijność w sekularyzowanych społeczeństwach. Zeszyty Naukowe KUL. 4 (236), ss. 3-26.

Nešpor, Z.R. 2018. Postsekularismus po česku? Ne/religiozita současné české společnosti mezi Východem a Západem. Střed. 1, ss. 101-118. 
Milerski, B. 2009. Edukacja religijna w szkole neutralnej światopogladowo. (Referat wygłoszony podczas IV Ekumenicznego Forum Katechetycznego, Warszawa-Radość, 15-16 maja 2009r.) - http://ekumenia.pl/files/konferencjePRE/Edukacja religijna w szkole neutralnej światopoglądowo B.Milerski).pdf (12.02.2019).

Nešpor, Z.R., 2010. Přiliš slábi ve víre. Česká ne/religiozita v evropském kontextu. Praha: Kalich.

Patočka, J. 1997. Kim sq Czesi? Kraków: Międzynarodowe Centrum Kultury. Rabušic, L., i Chromková-Manea, B.E., 2018. Hodnoty a postoje v České republice 1991-2017. Pramenná publikace European Values Study. Brno: Masarikova univerzita.

Różańska, A. 2010. Religijność czy duchowość młodzieży z pogranicza czesko-polskiego? W: Kardis, K. i Kardis, M. red. Nové náboženské hnutia, sekty a alternativna spiritualita v kontexte postmoderny. Prešov: Prešovská univerzita v Prešove, Gréckokatolícka teologická fakulta, ss. 351-364. Różańska, A. 2015. Edukacja religijna młodzieży w warunkach pluralizmu religijnego w wybranych krajach Europy Środkowo-Wschodniej (Grupa Wyszehradzka: Polska, Czechy, Stowacja, Wegry) - studium porównawcze. Cieszyn - Toruń 2015: Wydział Etnologii i Nauk o Edukacji Uniwersytetu Śląskiego w Katowicach, Wydawnictwo Adam Marszałek.

Taylor, Ch. 2007. Świecka epoka. Dlaczego porzucamy religię. Dziennik. 287, dodatek Europa, 49, ss. 12-13.

Václavík, D. 2010. Náboženství a moderní česká společnost. Praha: Grada Publishing.

Václavík, D., Hamplová, D. i Nešpor, Z.R., 2018. Religious situation in contemporary Czech society. Central European Journal of Contemporary Religion. 2, ss. 99-122.

Vlachová-Řeháková, K. 2004. Národ, kulturní identita a národní hrdost v Evropě. Czech Sociological Revue. 4, ss. 489-508.

Wallace, A. 1966. Religion. An anthropological view. New York: Random House.

Zenderowski, R. 2011. Religia a tożsamość narodowa i nacjonalizm w Europie Środkowo-Wschodniej. Między etnizacją religii a sakralizacją etosu (narodu). Wrocław: Wydawnictwo Uniwersytetu Wrocławskiego. 


\title{
(A)religiousness in the Czech way - atheism, religious illiteracy or something more?
}

\begin{abstract}
The article is an attempt to verify the thesis that contemporary Czech society is not an atheistic one, but can be a model example of multi-directional fierce secularization. The changes which occur in the Czech society are turning towards the shape of a multi-directional change of religiosity (transformation) with strong tendencies to secularization. They provide proofs of a soft, nevertheless, continuing secularization expressed in the pluralism of forms of religion which created a specific and complicated attitude of contemporary Czech society toward religion.
\end{abstract}

Keywords: contemporary religion, post-secularism, Czech Republic, religious illiteracy, religious pluralism

Translated by Aniela Różańska 